\title{
Nigerian Teachers’ Integration of Personal Response System into ESL Classroom
}

\author{
Alaba Olaoluwakotansibe Agbatogun \\ The University of Edinburgh, The Moray House School of Education \\ Edinburgh, EH8 8AQ, United Kingdom \\ E-mail: alabaagbatogun@yahoo.com
}

Received: June 22, 2011 Accepted: July 27, 2011 DOI: 10.5296/ije.v3i2.725

\begin{abstract}
In the last two decades, there has been the global clamour for the integration of emerging technologies into school curriculum; hence researchers and educators have had increased focus on technology integration in schools in order to have a shift of paradigm from the teacher-centred to student-centred classroom instruction. This study examined the predictive power of teachers' perceived usefulness (PU), perceived ease of use (PEU), behavioural intention (BI) to use Personal Response System (PRS) and computer experience (CE) on teachers' acceptance and attitude towards using PRS in improving communicative competence in the classroom where English is taught as a second language (ESL). Seventeen (17) teachers constituted the sample for the study. A self-report questionnaire and a semi-structured interview-guide were used for data collection. Descriptive statistics such as simple percentage, mean and standard deviation as well as inferential statistics such as Pearson Product Moment Correlation Coefficient, and Multiple regression were used for data analysis at 0.05 significance level. Results indicated that teachers were generally positively disposed to integrating PRS in ESL classrooms. Moreover, teachers' disposition was not significantly dictated by gender. Except for CE, constructs like PU, PEU and BI showed significant positive correlation with attitude to PRS. The results of regression analysis indicated that the set of variables combined to predict teachers' acceptance and attitude towards using PRS. Relatively, PU was the potent predictor of the dependent variable.
\end{abstract}

Keywords: Teachers, Personal response system, Intention to use, Second language, Nigeria 


\section{Introduction}

In the last decades, researchers and educators are having increased focus on technology integration in schools in order to transform the classroom from being teacher-centred to being student-centred. In view of this, Peake, Briers and Murphy (2005) remark that there has been an increase in the clamour for the integration of technological innovations into school curriculum. The impact of technology in education is more or less a burning issue to education researchers. Schools across the globe are therefore joining the technology revolution because teachers and learners are beginning to gain access to a wide range of technological innovations than ever before. Continuous advances towards integrating technology into classroom are being made so as to help learners' better understanding of curricular contents (Croxwall \& Cummings, 2000). Several innovative computer-linked technologies have been recorded to have been integrated into classrooms in developed countries. Such technologies include Internet, tablet computers, digital photography journals, MP3, interactive whiteboard, digital games, iPods etc (Friedman, 2006; Wozney, Venkatesh \& Abrami, 2006).

In many developing nations such as Nigeria, various Information and Communication Technologies (ICTs) are being introduced to school children with the hope of improving the quality of education learners are exposed to in the traditional teacher-centred classroom. For instance, despite the fact that English is the official language, national language, second language (L2), the language of instruction in schools from fourth year of primary education to tertiary level and a core subject in the school curriculum, Ekpo, Udosen and Afangideh (n.d) note that one of the pedagogical issues facing the teaching of English as a second language in most Nigerian primary schools is little or no interaction among the learners and between the teacher and the learners. Though Oyetunde (2002) remarks that success in the subject is a key to success in education, getting a good job and a major pre-requisite to post-secondary education. Ekpo, Udosen and Afangideh (n.d) and Olaniyan and Obadara (2008) found that the teaching of the subject has been designed after a stereotype type of learning that renders learners passive (chalk and talk method), inadequate instructional resources and many teachers' lack of creative ability to provide the right learning experiences that could encourage learners' development of necessary communicative competence. The resultant effect of learners' low facility in communicative competence has been reportedly reflecting in their low performances in school subjects over years (Adesemowo, 2005; Isiaka, 2007; Owuamanam \& Owuamanam, 2004). However, Ybarra and Green (2003) reiterate the fact that students learning a new language need a technology-rich environment that promotes learners' acquisition of language through interactive communication. Mojgan, Kamariah, Wong, Bahaman and Foo (2009) argue that every teacher is expected to use ICT to enhance teaching and learning of all subjects because they keep learners engage during the lesson and make them active participants of instructional process.

One of the emerging educational reforms is the encouragement of collaborative learning among learners. According to Chai, Hong and Teo (2009), collaborative learning occurs when learners co-construct knowledge and meaning with little input from the teacher. Pynoo et al. (2011) are of the opinion that in modern day of technology advancement, in order to promote knowledge co-construction and improved interaction in the classroom, teachers need to update 
their knowledge and skills so as to integrate technological innovations such as Personal Response System in teaching and learning process. According to Pelton, Pelton and Epp (2009), Personal Response System is gaining a widespread acceptance in educational setting in view of its interactive nature. Its description by many researchers has attracted different names that do not distort its meaning and functions in instructional process. According to MacArthur and Jones, PRS has been portrayed as Audience Response System (ARS), Audience Paced Feedback (APF), Classroom Communication System (CCM), Voting Machines (VM), Students' Response System (SRS), and Electronic Voting Machine (EVS). Trees and Jackson remark that a number of educators adopting PRS colloquially refer to it as "Clickers".

Meanwhile, Chu, Lu and Wann (2010) describe PRS as a remote control device which makes use of radio frequency (RF) information transfer. It's a device that permits immediate interaction between the teacher and the learners. The system consists of remote which the audience or students use to respond to questions and a radio frequency information recorder plugged into USB port of a computer laptop or a desktop. Through the RF, data are collected, recorded for onward display on the projection screen in form of bar chart. In summary, the major components of PRS include a handheld remote control, a receiver, the software installed on the computer and a projection system. Evaluating the functional value of PRS, Trees and Jackson (2007) report that PRS is being adopted by educators in order to foster deeper learning and increase classroom interaction, provide opportunity for learners to contribute their viewpoint during teaching and learning and give teachers opportunities to immediately evaluate learners' performance through immediate feedback displayed on projection screen.

Published reports on the use of PRS since the start of $21^{\text {st }}$ century indicate its effectiveness in the classroom (Crouch \& Mazur, 2001; Pollock, 2005). Empirical research findings further revealed that students exposed to PRS are more engaged in concept covered in the class (Siau, Sheng \& Nah, 2006; Simpson \& Oliver, 2007); students are more motivated in class discussion (Beatty, 2004); provide a new dimension of interactivity (Siau, Sheng \& Nah, 2006); increase students' participation in the class (Trees \& Jackson, 2007; 2008; MacArthur \& Jones, 2008), provide immediate feedback (Trees \& Jackson, 2007). Earlier researches on teachers' attitude toward the use of PRS indicate that clickers are easy to use (Hoffman \& Godwin, 2006). In a study of 659 students and 23 teachers Kay (2009) reports that attitude towards the use of PRS was influenced by gender. Mayer et al. (2009) also found that teacher had positive attitude towards the use of Personal Response System in large classes.

In an attempt to improve classroom interaction in Nigerian schools, lots of money is being expended on procuring technological hardware and software in schools as well as training teachers to effectively use the ICTs for instructional purposes. Unfortunately, education policy makers, curriculum developers and evaluators, the government at all levels, researchers and relevant stakeholders have seemingly given little attention to finding out the disposition of teachers towards integrating such prospective technological devices. According to Zhao and Cziko (2001), teachers are agents of change in relation to technological innovation integration in education. More importantly, ICTs may facilitate instruction but their potentials in education may become unrealisable if there is no change in teachers' pedagogical strategies that are dependent on teachers' support and right attitudes (Bangkok, 2004). Since teachers are the 
primary "gatekeepers" in terms of successful integration of technological initiatives in schools, their attitude is worth being studied because attitude is able to predict behavioural intention and actual behaviour. Teachers' attitudes whether positive or negative affect teachers' disposition towards the use of ICTs in schools. Teachers who believe that learners would learn better when they are exposed to the traditional "chalk and talk" method find it difficult to understand the need for students to explore the potential of computer-linked technologies for learning. Such ideology is a function of belief and attitude (Teo, Lee \& Chai, 2007).

Earlier research indicate that teachers' attitude towards integrating new technology in education is influenced by many factor; teachers' characteristics such as age, gender, computer experience, self-efficacy, computer knowledge, mental models and social demographic variables (Holden \& Rada, 2007); gender (Venkatesh \& Morris, 2000); compatibility degree of the technological innovation with the teachers' pedagogical beliefs (Zhao, Pugh, Sheldon \& Byers, 2002); perceived usefulness and perceived ease of use (Raaji \& Schepers, 2008); Siau, Sheng \& Nah, 2006); perceived contextual value (Tzeng, 2011); subject discipline (Teo, 2008); anxiety, confidence and liking (Yildrim, 2000); general usefulness and behavioural control and pedagogical use of technology (Yuen \& Ma, 2002). Meanwhile, the above identified variables and many more have been researched on as how they influence teachers' decision about whether to or not to integrate technology in the classroom. This study is however focused on computer literacy (CL), computer use (CU) and academic qualification in relation to teachers' attitude towards integrating Personal Response System in ESL classroom.

Successful integration of technological innovations in schools is more or less a reflection of teachers' level of computer literacy and frequency of computer use (Jenkins, 2009). Meanwhile, Kumar, Che Rose \& D' Silva (2008) opine that successful teachers in the new millennium require the acquisition of relevant computer skills in order to effectively integrate new technologies in schools. The significance of computer literacy in teachers' use of technology is not a new issue because the ability to use computer-technologies has been emphasised to be a function of teachers' level of computer skills and knowledge (Lam, 2000; Oh \& French, 2007; Shin \& Son, 2007). Computer literacy involves individuals' ability to use various software applications to accomplish specific purposes within a time limit, being able to use Internet to search information, possession of different types of skills to do various programming activities (Croxall \& Cummings, 2000; Jenkins, 2009). Meanwhile, Son \& Robb (2011) further list level of technological awareness, knowledge of computer components, concept of data and programmes, ways of data computing, working on files, documents and pictures and working with multimedia and communication as major indicators of computer literacy. Previous studies indicate that there exists a relationship between computer literacy and level of technology use (Jenkins, 2009); teachers' computer literacy was determined by technical training attended (Keane, 2002; Redman \& Kotrlik, 2004), access to ICT affects level of computer literacy (Ocak \& Akdemir, 2008) and computer literacy is a key to successful use of technology (Eisenberg \& Johnson, 1996).

Furthermore, teachers' ability to use computer-technology has been emphasised as a factor that influences their attitude towards integrating new technologies into school curriculum (Yushau, 2006). The way and manner ICTs are being utilised for instruction vary among teachers and 
schools. In developed countries, the use of technological devices has been taken as integral part of school curriculum. However, in developing nations like Nigeria, uptake of technology in education is relatively low. Some teachers are still of the opinion that the conventional methods of teaching is still relevant and results-oriented in the present days of technological advancement. Sa'ari, Wong and Roslan (2005) assert that if teachers are reluctant to integrating technology in schools, the best thing to do is to look for ways of having their attitude changed.

In a study conducted by Son and Robb (2011) on 73 in-service Indonesian EFL teachers, it was found that lack of computer skills affected their intention to use computers. More than ever before, educators are increasingly showing interest in how teachers' use ICTs to facilitate instruction in primary education. However, more high school teachers with higher academic degrees have been reported to display positive attitude towards the use of computers in schools more than their colleagues at primary schools (Grant \& Mims, 2010). Further findings on teachers' use of technology reveal that research favours teachers' use of technology for instruction and that teachers' limited access to ICTs affects effective use of computer-technologies (Ocak \& Akdemir, 2008; Pelgrum, 2001); teachers' technology use correlates with their computer confidence level (Atkins \& Vasu, 2000).

In order to understand teachers' technology use and acceptance, a well defined framework is important; hence this study was guided by the Technology Acceptance Model. The Technology Acceptance Model (TAM) developed by Davis (1989) is an adaptation of the Ajzen and Fishbein (1980) Theory of Reasoned Action (TRA) which is a parsimoniously theoretical and empirically justified model developed to describe technology usage. The model advocates that perceived usefulness and perceived ease of use are key primary indicators of attitude towards technology use (Kumar, Che Rose \& D'Silva, 2008). In order words, TAM posits that technology users' attitude is determined by their behavioural beliefs about the consequences of the behaviour on the part of the individuals. Akpinar and Bayramoglu (2008) assert that TAM is a very influential theory in technology acceptance.

TAM explains the extent to which the perceived ease of use and perceived usefulness predict the attitude towards the use of a technology, while attitude towards use indicates users' intention to use, which then indicates the actual use of the technology. Over the years, several research were carried out on TAM and the findings indicate that perceived usefulness is a major predictor of intention to use technology, while perceived ease of use was the second determinant of intention to use technology (Shih, 2004). Perceived usefulness and perceived ease of use are integral process of using computer-technologies (Kumar, Che Rose \& D'Silva, 2008), perceived usefulness positively correlated with behavioural intention to use technology (Chau \& Hu, 2002; Todorova \& Obsurg, 2009).

Empirical research have been conducted in developed countries (United States of America, Canada, Australia, Malaysia and United Kingdom) about integrating of PRS and assessing the effectiveness of Personal Response System in school curricular subjects like astronomy, geometry, physics, mathematics, engineering etc. However, regarding the use of PRS in enhancing effective teaching and learning, there is no known published piece of information on the use of PRS in ESL classroom at the primary education level. The use of PRS for teaching 


\section{Macrothink

and learning is new in Nigerian education system. Meanwhile, Teo, Lee and Chai (2007) emphasise that attitude to technology is a key indicator of technology usage, but there is a dearth of research on teachers' attitude towards the use of an interactive technology like PRS. This study therefore is carried out to investigate the impact of computer literacy, computer use and academic qualification on teachers' attitude towards the use of PRS in ESL classroom.

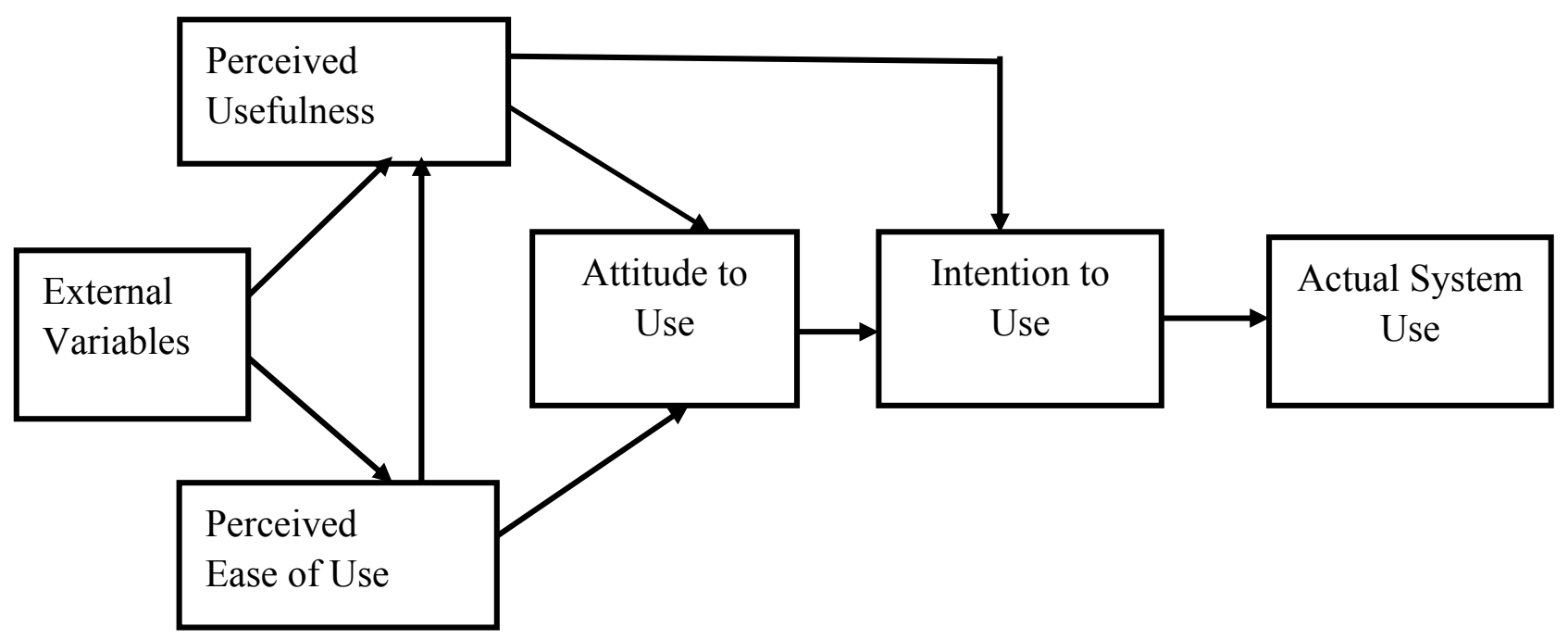

Figure 1. Technology Acceptance Model (Davis, 1989)

\section{Objective of the Study}

The focus of this study was to investigate Nigerian primary school teachers' attitude towards accepting and integrating Clickers in classroom where English is taught as a second language (L2) with a motive of improving the communicative skills of the learners. This study was guided by three research questions:

1. What is the overall profile of ESL primary school teachers' computer literacy and computer use?

2. What are the combined and relative contributions of computer literacy dimensions to the prediction of teachers' attitude towards the potential use of clickers in ESL classroom?

3. What are the combined and relative contributions of academic qualification, computer use and computer literacy to the prediction of teachers' attitude towards potential use of Clickers in ESL classroom?

\section{Method}

\subsection{Design}

The study was a descriptive study reporting data collected from teachers trained about effective why and how to effectively integrate Personal Response System in classroom where English is taught as a second language. 


\subsection{Participants}

Seventeen (17) teachers randomly selected from 7 primary schools in Ijebu-North local government of Ogun State, Nigeria constituted the sample for this study. All the teachers were selected for a 7-day training programme on effective use of Clickers in teaching English as a second language (L2). The major aims of the training included the following: to provide of the rationale and justify the integration of clickers into ESL classrooms; to facilitate teachers' effective integration of clickers into ESL classrooms and to provide the techniques and procedure involved in the integration of clickers in ESL classrooms. In the sample used for this study, there was 1 (5.9\%) Masters degree holder, 9 (52.9\%) Bachelor degree holder and 7 (41.2\%) Nigerian Certificate in Education holders. Furthermore, there were 10 female participants $(58.8 \%, \mathrm{M}=65.04,6.53)$ and 7 male participants $(41.2 \%, \mathrm{M}=66.00, \mathrm{SD}=5.03)$. The Mean Age and the Standard Deviation of the participants were 26.2 and 6.37 respectively.

\subsection{Instruments}

Data for this study were collected quantitatively through the use of Clickers Attitude Scale, Teachers Computer Literacy Questionnaire and Computer Use Questionnaire.

\subsubsection{Clickers Attitude Scale}

Clickers Attitude Scale was developed for this study based on reviewed literature (Gefen \& Straub, 2000; Selwyn, 1997; Teo, Lee, Chai \& Wong, 2009) on measurement items for TAM constructs (perceived usefulness, perceived ease of use, behavioural intention and attitude). The scale had two sections (A and B). Items in section A elicited participants' demographic data while the 21 items in section B were raised to examine teachers' attitude based on TAM constructs. Items were rated using four-point Likert scale ranging from strongly disagree (1) to strongly agree (4). Furthermore, items in section B of the instrument were modified in such a way to reflect the use of PRS rather than computers. The overall Cronbach alpha coefficient reliability of the measured constructs was .79 .

\subsubsection{Teachers' Computer Literacy Questionnaire}

The Teachers' Computer Literacy Questionnaire (TCLQ) developed at the University of Oregon was adapted for this study in view of the relevance and suitability of the items for collecting data on teachers' computer literacy level. TCLQ was used to measure and identify teachers' level of computer literacy under different dimensions. The original instrument containing 40 items was modified with a slight modification to the title instrument changed from Computer Literacy Survey to Teachers' Computer Literacy The instrument had two sections. The first section contained items that elicited respondents' demographic data, while the second section contained the 40 items with 10 items in each sub-scale of the four literacy dimensions examined in this study. The computer literacy dimensions were General Computer Knowledge, Documents and Documentation (word processing), Communication and Surfing (email, computer conferencing, and the Web), Data Inquiry (data bases and search engines). The total score of the entire 40 items was used as the computer literacy score. The Cronbach's alpha of the instrument yielded .89. Respondents' responses were rated using a 3-ponit Likert scale of 3 to 1 ranging from $2=$ Yes, $1=$ not sure, but likely and $0=$ no or unlikely. 


\subsubsection{Computer Use Questionnaire}

Computer use Questionnaire was researcher's self designed instrument developed after a review of literature on computer use (Ocak \& Akdemir, 2008; Kumar, Che Rose \& D'Silva, 2008; Teo, 2008). The instrument contained items requiring information on participants' number of years in computer usage, frequency of computer use within a week, a month and in a year. There were also 5 items that further gathered data on how participants' make use of computers. The items were "I am a computer user", "I am an effective computer user", "I use computers at home", "I use computers at school" and "I do not use computers. Respondents answered "Yes" or "No" to the items to indicate their level of computer usage. The Cronbach's alpha of the instrument yielded .71.

\subsection{Validity of Instruments}

In order to ascertain the validity of all the instruments, the items of the instruments were reviewed by a group of four experts: two lecturers of educational technology, a quantitative methods' researcher and a psychometrician. Before the final draft of the instruments were eventually produced, suggestions of the above mentioned experts were given due consideration and necessary corrections made

\subsection{Procedure}

A set of the eInstruction Interwrite Radio Frequency (RF) Personal Response System received as a long-term loan from the manufacturer was used for a 7-day training of the teachers in September, 2010. The training of the teachers took place in one of the classrooms at a primary school at Ijebu-North local government in Ogun State, Nigeria. At the commencement of the training, teachers were told that their participation was voluntary and that whosoever wanted to withdraw could do so at any time. All participating teachers were made to voluntarily fill, sign and return the teachers' consent form. This was done to ensure that the teachers were willingly and positively disposed to participating in the training. The training was conducted 5 hours in two sessions daily with 30 minutes break time in-between. The PRS was used alongside a laptop using the Microsoft PowerPoint programme, a data projector and a projection screen. In order to ensure teachers' mastery of the techniques involved in effective use of Personal Response System, all the teachers were given the opportunity to have practical demonstration of the knowledge gained during the training on the fifth and sixth days of the training. The teacher' attitude questionnaire was administered to all the teachers two days to the end of the training. There was $100 \%$ return of the questionnaire from all the 17 participants. Meanwhile, emphasis was laid on the fact that data gathered from the participants would be confidentially and anonymously used for research purposes.

\section{Results}

Overall computer literacy was measured in terms of general computer knowledge, document and documentation, data inquiry and communication and surfing. The participants scored highest in documents and documentation $(\mathrm{M}=21.80)$ followed by the communication and surfing $(M=19.08)$. General computer knowledge subscale had the least score $(M=14.41)$ while data inquiry subscale scored higher than general computer knowledge subscale $(\mathrm{M}=$ 
17.43). The means indicate that the participants were more skilled in documents and documentation, and communication and surfing than they were in general computer knowledge and data inquiry.

Table 1. Literacy dimensions

\begin{tabular}{lcccc}
\hline \multicolumn{1}{c}{ Subscale } & No of items & Mean & SD & Alpha \\
\hline Document and documentation & 10 & 21.7978 & 6.08868 & .90 \\
Communication and surfing & 10 & 19.0895 & 5.62692 & .85 \\
Data inquiry & 10 & 17.4343 & 5.52248 & .84 \\
General computer knowledge & 10 & 14.4081 & 4.50337 & .80 \\
\hline
\end{tabular}

Descriptive statistics and reliability coefficient for computer literacy dimensions

$$
(\mathrm{n}=40)
$$

Teachers' overall profile of computer use was measured by examining their frequency of computer usage and level of using computers. The results are presented in Tables 2 and 3 below:

Table 2. Computer use profile

\begin{tabular}{lr|r|r}
\hline & & $\mathrm{F}$ & $\%$ \\
\hline How often do you use computers? & Not at All & 3 & 16.7 \\
& A few times a Year & 6 & 33.3 \\
& A few times a Month & 5 & 27.8 \\
& A few times a Week & 3 & 16.7 \\
\hline How long have you been using computers? & $4-5$ Years & 1 & 5.6 \\
& $2-3$ Years & 7 & 38.9 \\
& 1 Year or less & 9 & 50.0 \\
\hline
\end{tabular}

Frequency of computer usage

As indicated in Table 2, regarding teachers' overall profile of computer use, majority of the teachers $(33 \%)$ rarely use computers in a year. More teachers use computers a few times per month $(27.8 \%)$ compared to those who claimed to use computers a few times a week and those who do not make use of computers at all. Similarly, half of the sampled teachers indicated they had up to one year experience of computer usage, while less than $6.0 \%$ of them reported to have had 4-5 years of computer usage.

Table 3 shows that over $50 \%$ of the teachers had opportunities to use computers at one time or the other. However, only one teacher was relatively competent in using computers. The results further show that not too many of the teachers had reasonable access to computers either at home or in the school. $3(17.65 \%)$ of the teachers also indicated that they do not use computers at all. The implication of the results in Tables 2 and 3 is that majority of the teachers are familiar with computers but they are not frequent and competent users of computers. 
Table 3. Computer use

\begin{tabular}{llrrr}
\hline & & \multicolumn{1}{c}{ Yes } & & No \\
& $\mathrm{f}$ & \multicolumn{1}{c}{$\%$} & $\mathrm{~F}$ & $\%$ \\
\hline I am a computer user & 9 & 52.94 & 8 & 47.06 \\
I am an effective computer user & 1 & 5.81 & 16 & 94.18 \\
I use computers at home & 6 & 35.29 & 11 & 64.71 \\
I use computers at school & 2 & 11.76 & 15 & 88.24 \\
I do not use computers & 3 & 17.65 & 14 & 82.35 \\
\hline
\end{tabular}

Level of using computers

The results in Table 4 showed the relationship among the computer literacy dimension subscales shown in Table 1. The outcome of the Pearson correlation analysis indicated that teachers' attitude towards clickers use significantly and positively correlated with documents and documentation computer literacy dimension, while general computer knowledge correlated positively and significantly with documents and documentation, data inquiry and communication and surfing computer literacy dimensions. Furthermore, there was a significant positive correlation between data inquiry computer literacy dimension and documents and documentation computer literacy dimension. All subscales correlate significantly and this suggests that the four elements were fairly independent to be used as measurement of computer literacy as well as independent variables for the study.

Table 4. Attitude and literacy dimensions

\begin{tabular}{lccccc}
\hline & A & B & C & D & E \\
\hline A. Attitude to Clickers & & $.446^{*}$ & & \\
B. General Computer Knowledge & & $.928^{*}$ & $.679^{*}$ & $.585^{*}$ \\
C. Documents and Documentation & $.446^{*}$ & $.928^{*}$ & & $.626^{*}$ & $.598^{*}$ \\
D. Data Inquiry & & $.679^{*}$ & $.626^{*}$ & & $.646^{*}$ \\
E. Communication and Surfing & & $.585^{*}$ & $.598^{*}$ & $.646^{*}$ & \\
\hline
\end{tabular}

$* \mathrm{P}<.05$

Descriptive Statistics and Correlations Matrix for the relationship between computer literacy dimensions and teachers' attitude to PRS

The results in Table 5 revealed that the independent variables (general computer knowledge, documents and documentation, data inquiry and communication and surfing computer literacy dimensions) jointly contributed a coefficient of multiple regression of .739 and a multiple correlation square of .652 to the prediction of primary school teachers attitude towards clickers' use in teaching English as a second language. By implication, 73.9\% of the total variance of the dependent variable was accounted for by the combination of the four independent variables. Moreover, the results further showed that the analysis of variance of the multiple regression data produced an F-ratio value significant at 0.05 level $\left(\mathrm{F}_{(4,12)}=8.488 ; \mathrm{p}\right.$ $<.05)$. The results of the relative contributions of the independent variables to the prediction of teachers' attitude towards the use of clickers in ESL classroom was that documents and documentation was the potent significant positive contributor to the prediction of teachers' 
attitude towards the use of clickers in ESL classroom $(\beta=1.268, t=3.138, p=.009)$, while communication and surfing made the next significant but negative contribution to the prediction of the dependent variable $(\beta=-.701, \mathrm{t}=-3.424, \mathrm{p}=.005)$. However, general computer knowledge and data inquiry dimension did not make any significant contribution to the prediction of teachers' attitude towards the use of clickers in ESL classroom.

Table 5. Literacy dimensions contributions

\begin{tabular}{llllrl}
\hline \multicolumn{1}{c}{$\begin{array}{l}\text { Unstandardized } \\
\text { Coefficients }\end{array}$} & \multicolumn{3}{l}{$\begin{array}{l}\text { Standardized } \\
\text { Coefficients }\end{array}$} \\
Model & \multicolumn{1}{c}{ B } & Std. Error & Beta & T & Sig. \\
\hline Constant) & 63.957 & 3.409 & & 18.759 & .000 \\
General Computer Knowledge & -.198 & .401 & -.208 & -.495 & .630 \\
Documents and Documentation & 1.309 & .417 & 1.268 & 3.138 & .009 \\
Data Inquiry & -.353 & .234 & -.336 & -1.508 & .157 \\
Communication and Surfing & -.904 & .264 & -.701 & -3.424 & .005 \\
\hline Model Summary & & & & & \\
Multiple R ${ }^{2}=.739$ & & & & & \\
Multiple R ${ }^{2}$ (Adjusted) $=.652$ & & & & & \\
Standard Error Estimate $=3.42782$ & & & & & \\
F $=8.488$ & & & & & \\
Sig. $=.002$ &
\end{tabular}

a. Dependent Variable: Attitude to Clickers $(\mathrm{P}<.05)$

Model summary, coefficient and t-value of multiple regression analysis of computer literacy dimensions and the outcome measure

Table 6. Descriptive Statistics and Correlations Matrix

\begin{tabular}{|c|c|c|c|c|}
\hline & A & $\mathrm{B}$ & $\mathrm{C}$ & $\mathrm{D}$ \\
\hline A. Attitude to Clickers & & & $.448 *$ & \\
\hline B. Computer Literacy & & & $-.692 *$ & \\
\hline C. Computer Use & $.448^{*}$ & $-.692 *$ & & \\
\hline D. Academic Qualification & - & - & - & \\
\hline Mean & 65.4375 & 72.7297 & 3.5294 & 2.5882 \\
\hline $\mathrm{SD}$ & 5.80914 & 19.03173 & 1.00733 & .71229 \\
\hline
\end{tabular}

Descriptive Statistics and Correlations Matrix for the relationship between the Predictor variables and the Outcome Variable

The results in Table 6 indicated the means and standard deviations of teachers' attitude to clickers, computer literacy, computer use and academic qualification variables. Meanwhile, 
the results indicated that attitude to clickers $(\mathrm{M}=65.4375, \mathrm{SD}=5.81)$, computer literacy $(\mathrm{M}$ $=72.7297, \mathrm{SD}=19.03)$, computer use $(\mathrm{M}=3.5294, \mathrm{SD}=1.01)$ and academic qualification $(\mathrm{M}=2.5882, \mathrm{SD}=.71)$. The results of the Pearson correlation also indicated that there was a significant positive correlation between computer use and teachers' attitude to clickers, while a negative but significant correlation existed between computer use and computer literacy. Meanwhile, teachers' academic qualification did not significantly correlate with other variables.

The results in Table 7 showed that a combination of the independent variables (computer literacy, computer use and academic qualification) contributed a coefficient of multiple regression of .593 and a multiple correlation square of .499 to the prediction of teachers' attitude towards the use of clickers in ESL classroom. The implication of this result is that $49.9 \%$ of the total variance of teachers' attitude towards the use of clickers in teaching English as a second language was accounted for by the combination of computer literacy, computer use and academic qualification. The result further showed that the analysis of variance of the multiple regression data produced an F-ratio of 6.302 was significant at 0.05 . Meanwhile, the results further showed that teachers' academic qualification did not make significant contribution to the prediction of their attitude towards the use of clickers in ESL classroom. In any case, computer use made the most significant contribution to the prediction of teachers' attitude towards the use of clickers in ESL classroom $(\beta=1.039, \mathrm{t}=4.232$, $\mathrm{p}$ $=.001$ ), while computer literacy made lesser significant contribution to the prediction of teachers' attitude towards the use of clickers in ESL classroom $(\beta=.794, t=3.098, p=.008)$.

Table 7. Computer literacy, use and academic qualification

\begin{tabular}{lrrrrr}
\hline & \multicolumn{2}{c}{ Unstandardized } & \multicolumn{2}{c}{ Standardized } \\
& Coefficients & Coefficients & & \\
& $\mathrm{B}$ & Std. Error & Beta & $\mathrm{t}$ & Sig. \\
\hline (Constant) & 23.664 & 9.982 & & 2.371 & .034 \\
Computer Literacy & .242 & .078 & .794 & 3.098 & .008 \\
Computer Use & 5.990 & 1.415 & 1.039 & 4.232 & .001 \\
Academic Qualification & 1.161 & 1.574 & .142 & .738 & .474 \\
\hline Model Summary & & & & & \\
Multiple R ${ }^{2}=.593$ & & & & & \\
Multiple R ${ }^{2}$ (Adjusted) $=.499$ & & & & & \\
Standard Error Estimate $=4.11377$ & & & & & \\
F $=6.302$ & & & & & \\
Sig. $=.007$ & & & & & \\
\hline
\end{tabular}

a. Dependent Variable: Attitude to Clickers $(\mathrm{P}<.05)$

Model summary, coefficient and t-value of multiple regression analysis of computer literacy, computer use, academic qualification and the outcome measure 


\section{Discussion}

Overall, the results of this study showed that the teachers' computer literacy tilted towards general computer knowledge as well as documents and documentation than data inquiry and communication and surfing. The teachers could be generally regarded to be average computer literates who probably understand the basic theoretical principles of computer usage rather having the necessary technical and practical operational skills that could enhance their effective and efficient use of computers. In fact, the teachers' seeming average level of computer literacy could be attributed to the availability and accessibility to computers at the cyber cafes, private small-scale computer business-centres and those possibly available at few computer training centres or workshops they had attended. In the same vein, teachers' low level of computer literacy could be attributed to the extent to which they individually explored computers for personal purposes that required their paying more attention to the very basics of computer applications like word-processing, spreadsheets and possibly presentation tools than taking advantage of computers for tasks and activities related to data inquiry, communication and surfing. In consonance with the outcome of this study, Slaouti and Barton (2007) and Theng Lau and Sim (2008) also found that teachers were more competent in word-processing than using other computer programmes.

Another outcome of this study was the joint contribution of the computer literacy dimensions (general computer knowledge, documents and documentation, data inquiry and communication and surfing). The observed $\left(\mathrm{F}_{(4,12)}=8.488 ; \mathrm{p}<.05\right)$ is a reliable evidence that the combination of the computer literacy dimensions in the prediction of teachers' attitude towards the use of Personal Response System from all indications was not by chance. It is therefore evidently clear that the coefficient of multiple regression of .739 and a multiple $\mathrm{R}$ square of .652 indicate the extent and magnitude of the relationship between computer literacy dimensions and teachers' attitude towards the potential use of Personal Response System in ESL classroom. Meanwhile, the strength of the joint predictive power of the independent variables (computer literacy dimensions) on the prediction of the teachers' attitude towards the use of Personal Response System was very strong and significant at 73.9\%. Although, there might be other variables which may require further investigations about their contribution to the prediction of teachers' acceptance and use of Personal Response System in ESL classroom, but the degree of prediction made by the variables of this study could be substantive enough to assert that teachers' potential use of PRS is predictable by a combination of the computer literacy dimensions. However, there seems to be a dearth of research conducted on the predictive power of computer literacy dimensions used in this study on teachers' intention to use PRS.

One of the outcomes of this study indicated that documents and documentation dimension of computer literacy was the potent predictor, while communication and surfing was the least significant predictor of teachers' attitude towards the use of PRS in ESL classroom. Teachers' positive attitude towards using PRS may probably be attributed to the fact that the use of PRS requires users' demonstration of presentation tools (PowerPoint) and word-processing skills, which many teachers seem to possess or perceive to possess. This research finding corroborates earlier research outcome that teachers' attitude towards the use ICT was greatly 
determined by their competence in creation and manipulation of files and folders, saving, deleting and printing documents skills (Intaganok, Waterworth, Andsarachulamanee, Grasaresom \& Homkome, 2008). Furthermore, the outcome of this study was in congruence with the finding of Cuckle, Clarke and Jenkins (2000) which reported that teachers' proficiency in word-processing and presentation tools puts them at vantage position in adopting ICT in schools. Similarly, lending credence to the outcome of this study, Theng Lau and Sim (2008) also submitted that above the use of online demos, hypermedia and multimedia and statistical tools, teachers competence in word-processing provoked their use of computers.

The results of this study further revealed that general computer knowledge and data inquiry dimensions did not make significant contribution to the prediction of teachers' attitude towards the use of Personal Response System in ESL classroom. This outcome is not surprising because by informal observation, many computer users seem not to be interested in having deep understanding and knowledge, acquisition of technical skills about computer hardware and software. Such notion is often held probably because the general belief is that acquiring such skills should be the concern of computer technology specialists, engineers and technicians, rather average users of computer-technology for personal and instructional purposes who are not and should not be saddled with responsibility of computer maintenance. The outcome of this study contradicts the findings of Rilling, Dalman, Dodson, Boyles and Pazvant (2005) and Vannatta and Fordman (2004) who reported that teachers' decision to use computer-linked technologies is dependent on the quality of their computer technical knowledge and skills. Also, the finding of Intaganok, Waterworth, Andsarachulamanee, Grasaresom and Homkome (2008) which reported that teachers' negative attitude towards the use of ICT was orchestrated by lack of computer general knowledge and technical skills was at variance with the outcome of this study.

Another finding of this study showed that a combination of computer use, computer literacy and academic qualification significantly contributed to the prediction of teachers' attitude towards the use of Personal Response in ESL classroom. The observed F-ration value of 6.302 is a reliable evidence that the combination of computer use, computer literacy and academic qualification as independent variables to predict teachers' attitude towards the use of Personal Response System in ESL classroom was not accidental. The results further showed that the coefficient of multiple regression of .593 and a multiple $\mathrm{R}$ square of .499 indicate the magnitude of the relationship between computer use, computer literacy, academic qualification, computer literacy and teachers' attitude towards the use of Personal Response System in ESL classroom. Meanwhile, the strength of the predictive power of the combined independent variables (computer use, academic qualification and computer literacy) on the outcome variable is strong and significant at $49.9 \%$ to show the linear relationship between the three predictor variables and the total variance in teachers' attitude towards the use of PRS in ESL classroom.

In examining the relative contributions of computer use, academic qualification and computer literacy to the prediction of the outcome variable, this study found that only computer use and computer literacy made significant contribution to the prediction of teachers' attitude towards the integration of PRS in ESL classroom. The implication of this outcome as supported by 
earlier research (Ocak \& Akdemir, 2008; Jenkins, 2009) is that a strong association tend to exist between computer literacy, computer use and readiness to integrate technology. Meanwhile, the contribution of computer use to the prediction of teachers' attitude towards the integration of PRS in ESL classroom was higher than that of computer literacy.

That computer use is the potent predictor of the teachers' attitude towards the use of PRS is quite interesting because one would have expected that teachers' level of computer literacy should be a motivator towards their use of technology and a further decision as whether to or not to integrate computer-linked technologies into instruction. The outcome of this study was at variance with the finding of Berner (2003) who found computer literacy as the most potent contributor to users' attitude towards the use of ICT. Similarly, Mojgan, Kamariah, Wong, Bahaman and Foo, (2009) reported that computer literacy was a pre-requisite above other factors to determining computer use and not the other way round as found in this study. It is obvious that many $21^{\text {st }}$ century teachers are familiar with the basic principles of computer operation. Therefore, that computer use had an edge over computer literacy in predicting teachers' attitude toward the integration of PRS in classroom in this study could probably be associated with the teachers' observed and experienced simplicity and ease of use associated with PRS technology in the classroom. Also lending support to the outcome of this study, Rakes and Casey (2000) who found that computer use greatly affects teachers' attitude towards technology integration.

It is important to note that academic qualification did not any significant contribution to teachers' attitude towards the integration of PES technology in ESL classroom. Of course, if learners at all levels of education are becoming computer aficionados, there is therefore no excuse for any $21^{\text {st }}$ century teacher irrespective of academic attainment or qualification to display negative perception and attitude towards emerging instructional technologies. However, the outcome of this study was not supported by Bauer and Kenton (2005) who found that teachers of higher educational qualification were more positively disposed than those who were lesser educationally qualified.

\section{Conclusion}

In the last few years, several studies have been conducted on the use and users' attitude towards the use Personal Response System at the secondary and post-secondary education levels. Many of these studies included samples in developed countries such as Canada, United Kingdom Australia, United States of America and South Africa. By introducing Personal Response System to African primary school teachers and measuring teachers' attitude to PRS technology integration in classroom where English is taught as a second language, this study contributes to the understanding of the fact that the simplicity of technology use would rather place teachers' ability to use computers over acquisition of computer technical skills to influence positive attitude towards technology integration in educational system. Similarly, teachers' positive attitude towards the use of Personal Response System is an indicator that ESL teachers assign PRS crucial roles in triggering effective communication as well as improving learners' understanding, participation and performance in English language classroom. Apparently, with 
the potential use of PRS in teaching English as a second language, teachers and learners are most likely to have a different perception of the subject.

While there is an abundance of anecdotal information that advocates the use of clickers to improve student achievement in school subjects, the outcomes of this study claim that ESL teachers irrespective of some teacher's factors are positively disposed to the integration of PRS into their lessons. Averagely, teachers perceive the use of clickers as a tool to promote high level of collaborative learning and communication among learners during ESL lessons. With a high level of enthusiasm, ESL teachers in developing countries like Nigeria are expressing the "will" to explore the potential of personal response system to improve the teaching and learning of English as a second language in order to improve learners' communicative competence. At the same time, with no significant contribution of academic qualification to the prediction of teachers' attitude to PRS integration, the study also bring to rest the unnecessary importance attached to differentials in teachers' attitude to technology integration based on academic qualification and educational attainment. It is therefore obvious that the complexity and difficulty level of technicality involved in technology operation triggers differences in attitude to technology use among the less, averagely and highly educated people.

Further research should be conducted in order to compare the attitude of ESL teachers with those of other subjects in all primary schools in Ogun State, and among all teachers across all states in Nigeria. Similarly, comparative studies among different levels of education system and between/among different countries on teachers' attitude towards the integration of PRS should be carried out by other researchers. Studies on teachers' attitude towards the integration of PRS should be carried out using some environmental, school, teachers, psychological factors and other factors as independent variables.

\section{References}

Ajzen, I., \& Fishbein, M. (1980). Understanding attitudes and predicting social behaviour. Englewood Cliffs, NJ: Prentice-Hall.

Akpinar, Y., \& Bayramoglu, Y. (2008). Promoting teachers' positive attitude towards Web use: A study in website development. The Turkish Online Journal of Educational Technology 7 I (3), 46-55. [Online] Available: http://www.tojet.net/articles/735.pdf

Atkins, N. E., \& Vasu, E. S. (2000). Measuring knowledge of technology usage and stages of concern about computing: A study of middle school teachers. Journal of Technology and Teacher Education, 8(4), 279-302. [Online] Available: http://www.editlib.org/p/8038.

Bangkok, U. (2004). Integrating ICTs into Education. [Online] Available: http://ddp-ext.worldbank.org/EdStats/IDNcas04.pdf (February15, 2011)

Bauer, J., \& Kenton, J. (2005). Technology integration in the schools: Why it isn't happening. Journal of Technology \& Teacher Education, 13, 519-526. [Online] Available: http://www.mendeley.com/research/toward-technology-integration-in-the-schools-why-it-isnt -happening/ 
Beatty, I. (2004). Transforming Student Learning with classroom communication Systems. EDUCAUSE Research Bulletin, (3), 1-13. [Online] Available: http://www.educause.edu/ir/library/pdf/ERB0403.pdf

Berner, J. E. (2003). A Study of Factors That May Influence Faculty in Selected Schools of Education in the Commonwealth of Virginia to Adopt Computers in the Classroom. (Abstract Doctoral Dissertation, George Mason University, ProQuest Digital Dissertations (UMI No. AAT 3090718).

Chai, C. S., Hong, H., \& Teo, T. (2009). Singaporean and Taiwanese pre-service teachers' beliefs and their attitude towards ICT: A comparative study. The Asia-Pacific Education Researcher, $18, \quad 117 \quad-\quad$ 128. [Online] Available: http://www.apsce.net/icce2008/contents/proceeding_0865.pdf

Chau, P.Y.K., \& Hu, P. J. (2002). Information technology acceptance by individual professionals: A model comparison approach. Decision Sciences, 32: 699-719. [Online] Available: http://onlinelibrary.wiley.com/doi/10.1111/j.1540-5915.2001.tb00978.x/abstract

Chu, H., Lu, T., \& Wann, J. (2010). Evaluation of the acceptance of audience response system by corporation using TAM. Communications in Computer and Information Science, 113, 281-291. [Online] Available: http://www.springerlink.com/content/v76kq5u0198156t1/

Crouch, C. H., \& Mazur, E. (2001). Peer instruction: Ten years of experience and results. American Journal of Physics, 69, 970 - 977. [Online] Available: http://web.mit.edu/jbelcher/www/TEALref/Crouch_Mazur.pdf_ doi:10.1119/1.137424, http://dx.doi.org/10.1119/1.137424

Croxall, K., \& Cummings, M.N. (2000). Computer usage in family and consumer sciences classrooms. Journal of Family and Consumer Sciences Education, 18 (1), 9-18, [Online] Available: http://www.natefacs.org/JFCSE/v18no1/v18no1Croxall.pdf

Cuckle, P., Clarke, S., \& Jenkins, I (2000). Students' information and communications technology skills and their use during teacher training. Journal of Information Technology for Teacher Education, 9(1), 9 - 22.

Davis, F. D. (1989). Perceived usefulness, perceived ease of use, and user acceptance of information technology. MIS Quarterly, 13(3), 319-34. [Online] Available: http://www.jstor.org/pss/249008

Eisenberg, M.B., \& Johnson, D. (1996). Computer skills for information problem-solving: Learning and teaching technology in context. [Online] Available: http://www.ericdigests.org/2003-1/skills.htm (January 11, 2011)

Ekpo, M, Udosen, A. E., \& Afangideh, M.E. (n.d.). Jolly phonics strategy and the ESL pupils' reading development: A preliminary study. A paper presented at $1^{\text {st }}$ Mid Term Conference held at the University of Ibadan, Ibadan, Oyo State, Nigeria. [Online] Available: http://www.steppingstonesnigeria.org/files/Reading_Skills.doc. 
Friedman, A. (2006). K-12 teachers' use of course websites. Journal of Technology and Teacher Education, 14, 795-81. [Online] Available: http://www.mendeley.com/research/k12-teachers-course-websites/

Gefen, D. (2000). E-Commerce: The Role of Familiarity and Trust. Omega: The International Journal of Management Science, 286, 725-737. [Online] Available: http://onemvweb.com/sources/sources/ecommerce_role_familiarity_trust.pdf

Hoffman, C., \& Goodwin, S. (2006). A clicker for your thought: technology for active learning. New Library World, 107 (9/10), 422 - 433. [Online] Available: http://www.citeulike.org/group/12747/article/6601862 doi:10.1108/03074800610702606, http://dx.doi.org/10.1108/03074800610702606

Holden, H. K., \& Rada, R. (2007). Assessing teachers' self-efficacy, perceived usability and attitude towards educational technology acceptance and usage. In G. Siemens \& C. Fulford (Eds.), Proceedings of World Conference on Educational Multimedia, Hypermedia and Telecommunications 2009 (pp. 848-857). Chesapeake, VA: AACE. [Online] Available: http://www.editlib.org/p/31597.

Intaganok, I., Waterworth, P., Andsavachulamanee, T., Grasaresom, G., \& Homkome, U. (2008). Attitudes of staff to information and communication technologies in a provincial University in Thailand. The Electronic Journal of Information Systems in Developing Countries, $33 \quad(3), \quad 1-\quad 14 . \quad$ [Online] Available: http://www.ejisdc.org/ojs2/index.php/ejisdc/article/view/307/242

Isiaka, B. (2007). Effectiveness of video as an instructional medium in teaching rural children agricultural and environmental sciences. International Journal of Education and Development using ICT, $3 \quad$ (3), $105 \quad-\quad$ 114. [Online] Available: http://ijedict.dec.uwi.edu/viewarticle.php?id=363

Jenkins, D., Mimbs, C.A., \& Kitchel, T. (2009). Computer literacy, access and use of technology in the family and consumer sciences classroom. Journal of Family and Consumer Sciences Education, 27(1), 1- 13. [Online] Available: http://www.natefacs.org/JFCSE/v27no1/v27no1Jenkins.pdf

Kay, R. H. (2009). Examining gender differences in attitudes towards interactive classroom communicative system. Computers \& Education, 52 (4), 730 -740. [Online] Available: http://portal.acm.org/citation.cfm?id=1508652 doi:10.1016/j.compedu.2008.11.015, http://dx.doi.org/10.1016/j.compedu.2008.11.015

Keane, K. (2002). Computer applications in the field of family and consumer science. Journal of Family and Consumer Sciences Education, 20 (2), 37-44, [Online] Available: http://www.natefacs.org/JFCSE/v20no2/v20no2Keane.pdf

Kumar, N., Che Rose, R. \& D'Silva, J. L. (2008). A review of factors impinges computer usage in education. Journal of Social Sciences 4 (2), 146-157, [Online] Available: http://www.akademik.unsri.ac.id/download/journal/files/scipub/jss42146-157.pdf 
Lam, Y. (2000). Technophilia vs. technophobia: A preliminary look at why second-language teachers do or do not use technology in their classrooms. Canadian Modern Language Review, $56 \quad(3), \quad 389-420 . \quad$ [Online] Available: http://utpjournals.metapress.com/content/151gw24858325408/ doi:10.3138/cmlr.56.3.389, http://dx.doi.org/10.3138/cmlr.56.3.389

MacArthur, J. R., \& Jones, L. L. (2008). A review of reports of clickers applicable to college chemistry classrooms. Chemistry education Research and Practice, 9, 187-195. [Online] Available: http://pubs.rsc.org/en/Content/ArticleLanding/2008/RP/b812407h doi:10.1039/B812407H, http://dx.doi.org/10.1039/B812407H

Mayer, R, Stull, A., DeLeeuw, K., Almeroth, K., Bimber, B., Chun, D., Bulge, M., Campbell, J., Knight, A., \& Zhang, H. (2009). Clickers in college classrooms: Fostering learning with questioning methods in large lecture classes. Contemporary Educational Psychology, 34 (1), $51 \quad-57 . \quad$ [Online] Available: http://www.mendeley.com/research/clickers-in-college-classrooms-fostering-learning-with-q uestioning-methods-in-large-lecture-classes/ doi:10.1016/j.cedpsych.2008.04.002, http://dx.doi.org/10.1016/j.cedpsych.2008.04.002

Mojgan, A., Kamariah, A., Wong, S., Bahaman, A. \& Foo, S. F. (2009). Factors affecting teachers' use of information and communication technology. International Journal of Instruction, 2 (1), $77 \quad-\quad$ 104. [Online] Available: http://www.e-iji.net/dosyalar/iji_2009_1_5.pdf

Ocak, M. A. \& Akdemir, O. (2008). An investigation of primary school teachers' use of computer applications. The Turkish Online Journal of Educational Technology, 7 (4), 54 - 60. [Online] Available: http://www.tojet.net/articles/746.pdf

Oh, E., \& French, R. (2007) Preservice teachers' perceptions of an introductory instructional technology course. CALICO Journal, 24(2), 253-267

Olaniyan, D.A.L., \& Obadara, O.E. (2008). A critical review of management of primary education in Nigeria. International Journal of African American Studies, 7(1), 1-19. [Online] Available: https://ojcs.siue.edu/ojs/index.php/ijaaas/article/viewFile/103/163

Owuamanam, D.O., \& Owuamanam, T.O. (2004). Fundamentals of Educational Psychology. Lagos: Bolabay Productions.

Oyetunde, T. O. (2002). Second language reading: Insight from Nigerian primary school. The Reading, 55 (8), 748-755. [Online] Available: http://www.jstor.org/pss/20205134

Peake, J.B., Briers, G., \& Murphy, T. (2005). Relationships between student achievement and levels of technology integration by Texas agriscience teachers. Journal of Southern Agricultural Education Research, 55(1), 19-32. [Online] Available: http://www.jsaer.org/pdf/Vol55/55-01-019.pdf 
Pelgrum, W.J. (2001). Obstacles to the Integration of ICT in Education: Results from a Worldwide Educational Assessment. Computers \& Education 37, 163- 17. [Online] Available: http://portal.acm.org/citation.cfm?id=542947

Pelton, T., Pelton, L. F., \& Epp, B. (2009). Clickers supporting teaching, teacher education, educational research and teacher development. In I. Gibson et al. (Eds.), Proceedings of Society for Information Technology \& Teacher Education International Conference 2009, pp. 1065-1070. Chesapeake, VA: AACE. [Online] Available: http://www.editlib.org/p/30746

Pollock, S. J. (2005). Transferring transformations: Learning gains, students attitudes, and the impacts of multiple instruction in large lecture courses. Physics Education Research Conference, Salt Lake City, Utah: August 10-11, 2005, pp 141-144. [Online] Available: http://www.colorado.edu/physics/EducationIssues/pollock/PERC_sum05_finalrevised.pdf

Pynoo, B., Devolder, P., Tondeur, J., van Braak, J., Duyck, W. \& Duyck, P. (2011). Predicting secondary school teachers' acceptance and use of a digital learning environment: A cross-sectional study. Computers in Human Behavior, 27 (1), 568-575. [Online] Available: http://portal.acm.org/citation.cfm?id=1890069 doi:10.1016/j.chb.2010.10.005, http://dx.doi.org/10.1016/j.chb.2010.10.005

Raaij, E. M. V., \& Schepers, J. J. L. (2008). The acceptance and use of a virtual learning environment in China. Computers \& Education, 50, 8384852. [Online] Available: http://portal.acm.org/citation.cfm?id=1342670 doi:10.1016/j.compedu.2006.09.001, http://dx.doi.org/10.1016/j.compedu.2006.09.001

Rakes, G. C., \& Casey, H. B. (2000). An analysis of teacher concerns toward instructional technology. International Journal of Educational Technology, 3(1). [Online] Available: http://www.ed.uiuc.edu/ijet/v3n1/rakes/index.html

Redmann, D. H., \& Kotrlik, J. W. (2004). Analysis of technology integration in the teaching learning process in selected career and technical education programs. Journal of Vocational Education Research, 29(1), 3-25. [Online] Available: http://acter.metapress.com/content/nx627586j427404u/

Rilling, S., Dahlman, A., Dodson, S., Boyles, C., \& Pazvant, O. (2005). Connecting CALL theory and practice in pre-service teacher education and beyond: Processes and products. CALICO Journal, 22 (2), 213-235. [Online] Available: https://calico.org/a-165-Connecting\%20CALL\%20Theory\%20and\%20Practice\%20in\%20Pre service $\% 20$ Teacher $\% 20$ Education $\% 20$ and $\% 20$ Beyond $\% 20$ Processes $\% 20$ and $\% 20$ Products.ht $\mathrm{ml}$

Sa'ari, J. R., Wong, S. L., \& Roslan, S. (2005). In-service teachers' views toward technology and teaching and their perceived competency toward information. Technology. Journal of Technology, 434 (E), 1-14. [Online] Available: http://www.penerbit.utm.my/onlinejournal/43/E/JTDIS43E1.pdf

Selwyn, N. (1997). Students' attitudes toward computers: Validation of a computer attitude scale for 16 - 19 education. Computer and Education 28 (1), 35-41. [Online] Available: 
http://portal.acm.org/citation.cfm?id=251911 doi:10.1016/S0360-1315(96)00035-8, http://dx.doi.org/10.1016/S0360-1315(96)00035-8

Shih, H.P. (2004). Extended technology acceptance model of internet utilization behavior. Information and Management, 41, 719-729. [Online] Available: http://www.sciencedirect.com/science/article/pii/S0378720603001216 doi:10.1016/j.im.2003.08.009, http://dx.doi.org/10.1016/j.im.2003.08.009

Shin, H.-J., \& Son, J. B. (2007). EFL teachers' perceptions and perspectives on Internetassisted language teaching. CALL-EJ Online, $\quad \begin{array}{llllll} & 8 & \text { (2), } & 1 & - & 13 .\end{array}$ http://eprints.usq.edu.au/1924/1/Shin_Son.pdf

Siau, K., Sheng, H., \& Nah, F. F. (2006). Use of classroom response system to enhance classroom interactivity. IEEE Transaction Education, 49 (3), 398 - 403. [Online] Available: http://digitalcommons.unl.edu/cgi/viewcontent.cgi?article $=1025 \&$ context=managementfacpu b doi:10.1109/TE.2006.879802, http://dx.doi.org/10.1109/TE.2006.879802

Simpson, V., \& Oliver, M. (2007). Electronic voting systems for lectures then and now: A comparison of research and practice. Australasian Journal of Educational Technology, 23(2), 187-208. [Online] Available: http://www.ascilite.org.au/ajet/ajet23/simpson.html

Slaouti, D., \& Barton, A. (2007). Opportunities for practice and development: newly qualified teachers and the use of information and communication technologies in teaching foreign languages in English secondary school contexts. Journal of In-service Education, 33 (4), 405 424.

Son, J. B., \& Robb, T. (2011). Computer literacy and competency: A survey of Indonesian teachers of English as a foreign language. Computer Assisted Language Learning Electronic Journal, 12 (1), 26 - 42. [Online] Available: http://eprints.usq.edu.au/18371/

Teo, T. (2008). Pre-service teachers' attitudes towards computer use: A Singapore survey. Australasian Journal of Educational Technology, 24 (4), 413 - 424. [Online] Available: http://www.ascilite.org.au/ajet/ajet24/teo.pdf

Teo, T., Lee, C. B., \& Chai, C. S. (2008). Understanding pre-service teachers' computer attitudes: Applying and extending the Technology Acceptance Model (TAM). Journal of Computer Assisted Learning, 24 (2), 128-143. [Online] Available: http://www.mendeley.com/research/understanding-preservice-teachers-computer-attitudes-ap plying-and-extending-the-technology-acceptance-model/

doi:10.1111/j.1365-2729.2007.00247.x, http://dx.doi.org/10.1111/j.1365-2729.2007.00247.x

Teo, T., Lee, C. B., Chai, C. S., \& Wong, S. L. (2009). Assessing the intention to usetechnology among pre-service teachers in Singapore and Malaysia: A multigroup invariance analysis of the technology acceptance model (TAM). Computers \& Education, 53, 1000-1009. [Online] Available: http://cgit.nutn.edu.tw:8080/cgit/PaperDL/TKW_100510125529.PDF doi:10.1016/j.compedu.2009.05.017, http://dx.doi.org/10.1016/j.compedu.2009.05.017 
Theng Lau, B., \& Sim, C. H. (2008). Exploring the extent of ICT adoption among secondary school teachers in Malaysia. International Journal of Computing and ICT Research, 2 (2), 19 36. [Online] Available: http://www.ijcir.org/volume2-number2/article3\%2019-36.pdf

Todorova, A., \& Osburg, Th. (2009). Intel® Teach - Advanced Online: Teachers' Use of and Attitudes Toward Online Platform for Professional Development. Paper presented at the International Conference on Interactive Computer-aided Learning, 24-26 September 2009, Villach, Austria. [Online] Available: http://consortium.teach-advanced-online.org/file.php/1/resources/ICL_Villach.pdf

Trees, A. R., \& Jackson, M. H. (2007). The learning environment in clicker classrooms: Student processes of learning and involvement in large university-level courses using student response systems. Learning, Media and Technology, 32(1), 21-40. [Online] Available: http:/www.kent.edu/fpdc/technology/clickers/upload/the-learning-environment-in-clicker-cla ssrooms-student-processes-of-learning-and-involvement-in-large-university-level-courses-usi ng-student-response-systems.pdf

Tzeng, J. (2011). Perceived values and prospective users' acceptance of prospective technology: The case of career e-portfolio system. Computers \& Education, 56 (1), 157-165. [Online] Available: http://www.sciencedirect.com/science/article/pii/S0360131510002319 doi:10.1016/j.compedu.2010.08.010, http://dx.doi.org/10.1016/j.compedu.2010.08.010

Vannatta, R. A., \& Fordham, N. (2004). Teacher dispositions as predictors of classroom technology use. Journal of Research on Technology in Education, 36, 253-271, [Online] Available:

http://eec.edc.org/cwis_docs/NEWS_ARTICLES_JOURNALS/Assessment_in_Ed/vanetta.p df

Venkatesh, V., and Morris, M. G. (2000). Why do not men ever stop to ask for directions? Gender, social influence and their role in technology acceptance and usage behavior. MIS Quarterly, 24: 115-139. [Online] Available: http://www.jstor.org/pss/3250981

Wozney, L., Venkatesh, V., \& Abrami, P.C. (2006). Implementing computer technologies: teachers' perceptions and practices. Journal of Technology and Teacher Education, 14, 173-207.

[Online]

Available:

http://doe.concordia.ca/cslp/cslp_cms/sites/all/themes/jframe/downloads/PDF/wozneyetaljtte 141.pdf

Ybarra, R., \& Green, T. (2003). Using technology to help ESL/EFL students develop language skills. The Internet TESL Journal, (9), 3. [Online] Available: http://iteslj.org/Articles/Ybarra-Technology.html

Yildirim, S. (2000). Effects of an educational computing course on pre-service and inservice teachers: A discussion and analysis of attitudes and use. Journal of Research on computing in Education, 3, 479-495. [Online] Available: http://www.mendeley.com/research/effects-educational-computing-course-preservice-inservi ce-teachers-discussion-analysis-attitudes-use-6/ 


\section{Macrothink}

International Journal of Education ISSN 1948-5476 2011, Vol. 3, No. 2: E2

Yuen, A., \& Ma, W. (2002). Gender Differences in Teacher Computer Acceptance. Journal of Technology and Teacher Education, 10 (3), 365-38. [Online] Available: http://stu.hksyu.edu/ wkma/ref/Yuen_Ma_2002.pdf

Zhao, Y., \& Cziko, G. A. (2001). Teacher adoption of technology: A perceptual-control-theory perspective. Technology and Teacher Education 9(1), 5-30. [Online] Available: http://www.editlib.org/noaccess/8455

Zhao, Y., Pugh, K., Sheldon, S., \& Byers, J. L. (2002). Conditions for classroom technology innovations. Teacher College Record, 104(3), 482-515. [Online] Available: http://students.ed.uiuc.edu/mglund/files/zhao.pdf

\section{Copyright Disclaimer}

Copyright reserved by the author(s).

This article is an open-access article distributed under the terms and conditions of the Creative Commons Attribution license (http://creativecommons.org/licenses/by/3.0/). 